(C) 2016

Карпенко Н. Г., кандидат економічних наук

Полтавська державна аграрна академія

\title{
ОСНОВНІ ВИМОГИ ФОРМУВАННЯ ПОДАТКОВОЇ ЗВІТНОСТІ БЮДЖЕТНИМИ УСТАНОВАМИ
}

\section{Рецензент - доктор економічних наук В. Я. Плаксіснко}

У статті досліджено порядок складання та подання податкової звітності бюджетними установами, розглянуто організаційні етапи формування податкової звітності. В роботі окреслено джерела інформачї для визначення розміру платежів, зборів та формування податкової звітності. Звернуто увагу на основні обов'язкові відомості податкової звітності та реквізити заповнення форм звітності. За результатами дослідження акиентовано увагу на відповідальність посадових осіб за своєчасну сплату платежів та зборів, формування та подання звітності бюджетних установ.

Ключові слова: податки, неприбуткова організачія, реєстр, кодекс, декларація, звіт, податковий розрахунок, відповідальність, терміни, джерела.

Постановка проблеми. 3 метою оподаткування центральний орган державної податкової служби, відповідно до вимог ст. 157.12 Податкового кодексу, веде реєстр усіх неприбуткових організацій [3]. Право неприбуткової організації на користування пільгами виникає після внесення такої організації в Реєстр. Бюджетні установи, що не мають на меті отримання прибутку, відносяться до складу неприбуткових організацій та $\epsilon$ платниками податків до бюджету на загальних підставах.

Утримуються бюджетні установи за рахунок коштів загального та спеціального фондів Державного бюджету України та місцевих бюджетів. Бюджетні установи мають право вести діяльність виключно в межах асигнувань, затверджених кошторисами і планами асигнувань, дотримуючись фінансово-бюджетної дисципліни i максимальної економії матеріальних засобів і грошових коштів. Результати фінансово-господарської діяльності бюджетні установи в обов'язковому порядку відображають документально, складаючи різні види та форми звітності.

Бухгалтерська звітність - завершальний етап облікового процесу, що грунтується на даних синтетичного та аналітичного обліку установи і відображає майновий та фінансовий стан. Своєчасно та правильно складена та подана звітність характери- зує стан бюджетної установи, компетенцію та відповідальність її керівництва, що підкреслює актуальність теми дослідження.

Аналіз останніх досліджень і публікацій, у яких започатковано розв'язання проблеми. Порядок формування звітності бюджетної установи розглядається на сторінках наукових та спеціальних періодичних видань. Найбільше уваги питанню формування звітності приділяється зі сторони таких вчених та практиків, як С. М. Лістрова, Н. І. Сушко, І. Т. Ткаченко та інші.

Метою статті $\epsilon$ дослідження законодавства та його змін спрямованих на вдосконалення порядку формування та подання податкової звітності бюджетних установ.

Результати дослідження. Доходи бюджетної установи, як неприбуткової установи, звільняються від обкладання податками за умови, що надані нею платні послуги пов'язані зі статутною діяльністю і надходження та видатки за ними включено до їі кошторису відповідно до вимог ст. 157.2 Податкового кодексу [3].

Варто пам'ятати, що стосовно бюджетних установ законодавством передбачено значний перелік пільг під час визначення бази оподаткування, що викладено в Довіднику № 65-2 інших податкових пільг, затвердженому 29 березня 2013 р. Державною податковою службою для користування з 1 квітня 2013 р. Держава для бюджетних установ надає значну кількість пільг, що, однак, не позбавляє необхідності складання звітів, визначення суми наданих пільг та розкриття напрямів їх використання. Відповідно до посадових інструкцій та наказу про облікову політику складання та подання звітності проводиться спеціалістами, що відповідають за правильність нарахування та своєчасність сплати податків, платежів, внесків та зборів. До моменту складання податкової звітності в установі проведено організаційні заходи по реєстрації установи як платника податків, організації обліку нарахування та сплати податків і зборів та складання податкової звітності, як зображено на рисунку. 


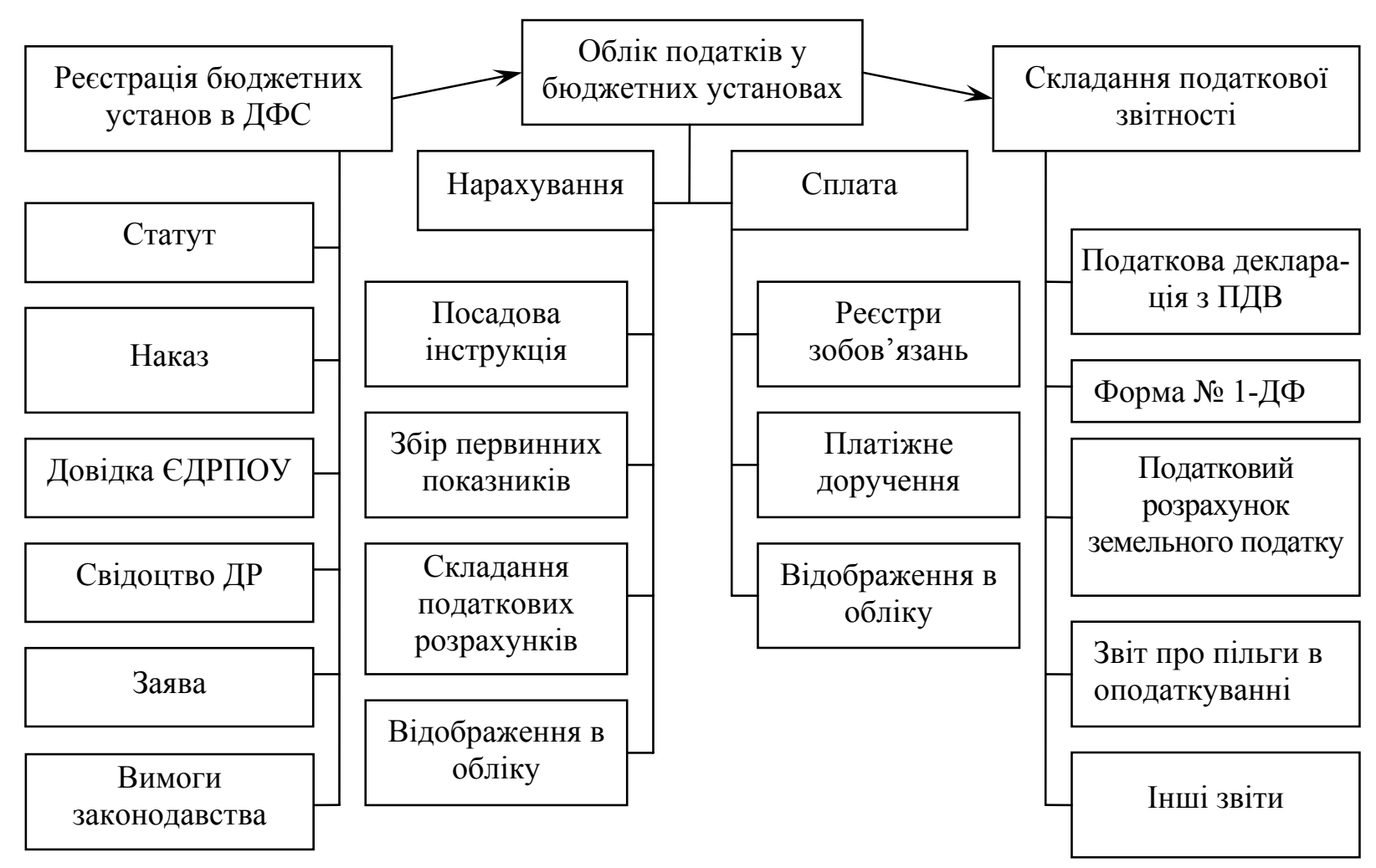

Рис. Організаційні етапи податкової звітності

Джерело: розробка автора

Порядок оподаткування неприбуткових установ визначений згідно з Податковим кодексом України. Нарахування податків та зборів бюджетною установою здійснюється за визначеною Податковим кодексом та іншими законодавчими актами методикою. Нараховані податки відносяться на видатки установи за КЕКВ 2800 «Інші поточні видатки» в кореспонденції з субрахунком 641 «Розрахунки за податками та платежами».

Податкова звітність складається на підставі даних обліку та дає інформацію про стан розрахунків з бюджетом за податками та зборами. До нарахування і сплати будь-якого виду податку чи збору (обов'язкового платежу) припускають здійснення належним чином розрахунку і обліку, результати яких відображаються у відповідній формі податкової звітності.

Податкова звітність являє собою сукупність дій платника податків (або особи, що його представляс) і податкового органу зі складання, ведення і здачі документів установленої форми, що містять відомості про результати діяльності платника податку, його майнове становище і фіксують процес обчислення податку, а також суму, що підлягає сплаті до бюджету.

Залежно від терміну подання податкова звіт- ність поділяється на: місячну, квартальну та річну. Відповідно до вимог Податкового Кодексу України існують такі терміни подання податкової звітності [3]:

a) календарний місяць - протягом 20 календарних днів, наступних за останнім календарним днем звітного (податкового) місяця;

б) календарний квартал або календарне півріччя - упродовж 40 календарних днів, наступних за останнім календарним днем звітного (податкового) кварталу (півріччя);

в) календарний рік - протягом 60 календарних днів за останнім календарним днем звітного (податкового) року.

До Центру обслуговування платників Міністерства доходів і зборів подається також інформація про нарахування та сплату єдиного соціального внеску та військового збору за новими формами звітності.

Форми податкової звітності розробляються та затверджуються наказами Державної податкової служби України до 2012 року та Міністерства доходів та зборів України (з 24 грудня 2012 р.) під час затвердження інструкції про порядок обчислення та сплати відповідного податку чи збору, що оновлюються у разі зміни [2]. 


\section{ЕКОНОМІКА}

Податкова звітність містить такі обов'язкові відомості:

1) ідентифікаційний код платника податку;

2) повне найменування платника податку, відомості про його місцезнаходження;

3) період, за який подається звіт, розрахунок, декларація чи дата, станом на яку подається звітність;

4) дату подання до податкового органу податкової звітності;

5) розмір бази оподаткування;

6) суму і розмір витрат і пільг;

7) суму, що не оподатковується податком;

8) ставку оподаткування;

9) суму податку, що підлягає сплаті;

10) підписи керівника і головного бухгалтера, печатка;

11) відмітка центру обслуговування платників про прийняття звітності.

Інформація для складання податкової звітності отримується 3 даних бухгалтерського обліку в залежності від вимог звіту, декларації чи розрахунку. Та основними джерелами інформації для складання звітності будуть книга «ЖурналГоловна», картки аналітичного обліку доходів, видатків [1]. Звітний документ підписується керівником та головним бухгалтером, факт подання в податкову службу засвідчується підписом спеціаліста Центру обслуговування платників Міністерства доходів і зборів за територіальним

\section{БІБЛІОГРАФІЯ}

1. Бюджетні установи: бухгалтерський облік та оподаткування : [навчальний посібник за ред. В. I. Лемішовського]. - Львів : Національний університет «Львівська політехніка» (Інформаційно-видавничий цент «Інтелект+» Інституту післядипломної освіти), «Інтелект-Захід», 2007. 1104 c.

2. Наказ Міністерства фінансів України «Про затвердження Змін до Порядку складання фінан- підпорядкуванням.

Контроль за виконанням розрахунків та оплати залишається на керівникові фінансової служби установи. Подання звітності до державної податкової служби відбувається через електронну пошту та підтверджується на магнітних та паперових носіях.

Складання та подання податкової звітності регулює податкове законодавство України. Платник податків, що не подає податкову звітність у строки, визначені законодавством, допускає неповне сплачення нарахованих платежів та зборів, сплачує штраф за кожне таке неподання, його затримку або неповну сплату. Відповідальність за неподання, несвоєчасне подання або наведення недостовірних даних щодо нарахованих та сплачених доходах та податках передбачена ст. 119 п. 2 Податкового кодексу та становить 510 грн. за вперше виявлені порушення. За інші види порушень та повторно вчинені неправомірні дії платника податку штрафні санкції передбачено в статтях глави 11 Податкового кодексу [3].

Висновок. Отже, використовуючи визначені законодавством форми податкової звітності, вчасно формуючи звіти та відображаючи результати фінансової діяльності бюджетна установа неприбуткова організація - забезпечує виконання власного кошторису і формування місцевого чи державного бюджету, дотримання вимог податкового законодавства.

сової та бюджетної звітності розпорядниками та одержувачами бюджетних коштів» № 1339 від 17 груд. 2012 р. [Електронний ресурс] / Верховна Рада України. - Режим доступу : http://www.rada. gov.ua.

3. Податковий кодекс України № 2755-VI від 2.12.2010 p. [Електронний ресурс] / Верховна Рада України. - Режим доступу : http://www.rada. gov.ua. 